medRxiv preprint doi: https://doi.org/10.1101/2021.07.26.21261082; this version posted July 28,2021 . The copyright holder for this preprint (which was not certified by peer review) is the author/funder, who has granted medRxiv a license to display the preprint in perpetuity.

All rights reserved. No reuse allowed without permission.

\title{
Altered pre-existing SARS-CoV-2-specific T cell responses in elderly individuals
}

Naoyuki Taira ${ }^{1}$, Sakura Toguchi ${ }^{1}$, Mio Miyagi ${ }^{1}$, Tomoari Mori ${ }^{2}$, Hiroaki Tomori ${ }^{3}$, Koichi Oshiro $^{4}$, Osamu Tamai ${ }^{5}$, Mitsuo Kina ${ }^{6}$, Masatake Miyagi ${ }^{7}$, Kentaro Tamaki ${ }^{8}$, Mary K Collins $^{9}$, and Hiroki Ishikawa ${ }^{1}$

${ }^{1}$ Immune Signal Unit, Okinawa Institute of Science and Technology, Graduate University (OIST), Onna-son, Okinawa, Japan.

${ }^{2}$ Research Support Division, Occupational Health and Safety, OIST, Onna-son, Okinawa, Japan

${ }^{3}$ Yaesu Clinic, Naha-city, Okinawa, Japan

${ }^{4}$ Ohama Daiichi Hospital, Naha-city, Okinawa, Japan

${ }^{5}$ Akebono Clinic, Naha-city, Okinawa, Japan

${ }^{6}$ Kina Clinic, Naha-city, Okinawa, Japan

${ }^{7}$ Arakawa Clinic, Naha-city, Okinawa, Japan

${ }^{8}$ Naha-Nishi Clinic, Department of Breast Surgery, Naha-city, Okinawa, Japan

${ }^{9}$ Research Support Division, Office of the Provost, OIST, Onna-son, Okinawa, Japan.

Corresponding author

Hiroki Ishikawa PhD

hiroki.ishikawa@oist.jp

Tel: 81-098-966-1601 
medRxiv preprint doi: https://doi.org/10.1101/2021.07.26.21261082; this version posted July 28,2021 . The copyright holder for this preprint (which was not certified by peer review) is the author/funder, who has granted medRxiv a license to display the preprint in perpetuity.

All rights reserved. No reuse allowed without permission.

\section{Abstract}

Pre-existing SARS-CoV-2-specific T cells, but not antibodies, have been detected in some unexposed individuals. This may account for some of the diversity in clinical outcomes ranging from asymptomatic infection to severe COVID-19. Although age is a risk factor for COVID-19, how age affects SARS-CoV-2-specific T cell responses remains unknown. We found that some pre-existing T cell responses to specific SARS-CoV-2 proteins, Spike (S) and Nucleoprotein $(\mathrm{N})$, were significantly lower in elderly donors ( $>70$ years old) who were seronegative for $\mathrm{S}$ than in young donors. However, substantial pre-existing $\mathrm{T}$ cell responses to the viral membrane $(\mathrm{M})$ protein were detected in some elderly donors. These responses likely compensate for loss of $\mathrm{T}$ cell responses specific to $\mathrm{S}$ and $\mathrm{N}$. In contrast, young and elderly donors exhibited comparable T cell responses to $\mathrm{S}, \mathrm{N}$, and $\mathrm{M}$ proteins after infection with SARS-CoV-2. M-specific responses were mediated by CD4 T cells producing interferon- $\gamma$ in both seronegative and seropositive individuals. $T$ cells in seronegative elderly donors responded to various M-derived peptides, while the response after SARS-CoV-2 infection was apparently focused on a single peptide. These data suggest that diversity of target antigen repertoire for pre-existing SARS-CoV-2-specific T cells declines with age, but the magnitude of pre-existing $\mathrm{T}$ cell responses is maintained by $T$ cells reactive to specific viral proteins such as $\mathrm{M}$. A better understanding of the role of pre-existing SARS-CoV-2-specific T cells that are less susceptible to age-related loss 
medRxiv preprint doi: https://doi.org/10.1101/2021.07.26.21261082; this version posted July 28,2021 . The copyright holder for this preprint (which was not certified by peer review) is the author/funder, who has granted medRxiv a license to display the preprint in perpetuity.

All rights reserved. No reuse allowed without permission.

may contribute to development of more effective vaccines for elderly people.

\section{Introduction}

There is extensive individual variation in severity of coronavirus disease 2019 (COVID-

19), caused by severe acute respiratory syndrome coronavirus 2 (SARS-CoV-2), ranging

61 from asymptomatic infection to fatal pneumonia (1). Various factors, including age, sex,

62 and comorbidities such as obesity and diabetes, influence the risk of severe COVID-19

63 (2-4). For example, morbidity and mortality among the elderly are significantly higher

64 than among the young (2). Consideration of protective measures for individuals vulnerable to COVID-19 should be particularly important to control the pandemic (5).

However, the cellular and molecular bases of the variable risk of COVID-19 remain poorly understood. to SARS-CoV-2 infection $(6,7)$. The magnitude and quality of $\mathrm{T}$ cell responses induced by SARS-CoV-2 infection are highly heterogeneous and are likely associated with

71 COVID-19 clinical outcomes. For example, SARS-CoV-2-specific T cell numbers and their interferon- $\gamma($ IFN- $\gamma)$ expression in severe COVID-19 patients are lower than in mild

COVID-19 patients (8-10). Furthermore, asymptomatic COVID-19 patients tend to have 
medRxiv preprint doi: https://doi.org/10.1101/2021.07.26.21261082; this version posted July 28,2021 . The copyright holder for this preprint (which was not certified by peer review) is the author/funder, who has granted medRxiv a license to display the preprint in perpetuity.

All rights reserved. No reuse allowed without permission.

74 increased SARS-CoV-2-specific T cells expressing higher levels of IFN- $\gamma$ compared to symptomatic patients (11). This individual variation in $\mathrm{T}$ cell responses may be partly explained by heterogeneity in levels of pre-existing SARS-CoV-2-reactive T cells. Some individuals who have not been exposed to SARS-CoV-2 have nonetheless acquired SARS-CoV-2-reactive T cells, probably through exposure to other common cold coronaviruses (12-14). Pre-existing CD4 and CD8 memory T cells, specific to various

SARS-CoV-2 proteins, including the structural proteins, Spike (S), Membrane (M), and Nucleoprotein $(\mathrm{N})$, have been detected with significant individual variation (D. Wyllie et al., manuscript posted on medRxiv DOI: 10.1101/2020.11.02.20222778). These preexisting SARS-CoV-2-reacive $\mathrm{T}$ cells are associated with immune protection against COVID-19; however, in other cases, they may exacerbate COVID-19 severity $(15,16)$. As many of the current vaccines express the SARS-CoV-2 S protein, only pre-existing Sreactive $\mathrm{T}$ cells are activated by these vaccines (Refs. 17 and L. Loyal et al., manuscript posted on medRxiv DOI: 10.1101/2021.04.01.21252379). Several studies have reported age-related differences in SARS-CoV-2-specific T cell responses in COVID-19 patients 
medRxiv preprint doi: https://doi.org/10.1101/2021.07.26.21261082; this version posted July 28,2021 . The copyright holder for this preprint (which was not certified by peer review) is the author/funder, who has granted medRxiv a license to display the preprint in perpetuity.

All rights reserved. No reuse allowed without permission.

93 and $\mathrm{M}$ antigens between young and elderly donors. The relatively elderly Okinawan

94 population, and the moderate rate of SARS-CoV-2 infection in Okinawa, allowed us to

96 individuals. We found that pre-existing $\mathrm{T}$ cell responses to $\mathrm{S}$ and $\mathrm{N}$ antigens are

97 significantly impaired in elderly donors compared to young donors, but a proportion of

98 elderly donors exhibit significant, high levels of M-reactive T cell responses. These data cells. 
medRxiv preprint doi: https://doi.org/10.1101/2021.07.26.21261082; this version posted July 28,2021 . The copyright holder for this preprint (which was not certified by peer review) is the author/funder, who has granted medRxiv a license to display the preprint in perpetuity.

\section{Methods}

\section{Subjects}

112 The study design was approved by the Okinawa Institute of Science and Technology,

113 Graduate University (OIST) human subjects ethics committee (applications HSR-2020-

114 024, HSR-2020-028). All donors provided informed written consent. Young (20 to 50

115 years of age, $n=66$ ) and elderly volunteers (over 70 years of age, $n=52$ ) were recruited in

116 Okinawa, Japan, between October, 2020 and April, 2021. 90 donors (48 young and 42

117 elderly) had no history of COVID-19, while 28 donors (18 young and 10 elderly) who

118 recovered from COVID-19 had positive COVID-19 PCR test results 1-3 months before

119 blood collection. Plasma from each donor was tested for SARS-CoV-2-specific antibodies

120 using SARS-Cov-2 Antibody Detection Kits (KURABO RF-NC001, RF-NC002) or

121 Cellex qSARS-Cov-2 IgG/IgM Cassette Rapid Tests (Cellex 5513C). Four (3 young and

1221 elderly) of 90 donors who had no history of COVID-19 and 26 (16 young and 10

123 elderly) of 28 donors who had recovered from COVID-19 were seropositive for SARS-

$124 \mathrm{CoV}-2 \mathrm{~S}$ antigen. Based on antibody test results, donors were grouped into seronegative

125 young ( $\mathrm{n}=45,40 \%$ male, 60\% female; mean age 38 years, age rage 23-49 years),

126 seronegative elderly $(n=41,17 \%$ male, $83 \%$ female; mean age 81 years, age rage $70-93$

127 years), seropositive young $(\mathrm{n}=19,63 \%$ male, $37 \%$ female; mean age 41 years, age rage 
medRxiv preprint doi: https://doi.org/10.1101/2021.07.26.21261082; this version posted July 28,2021 . The copyright holder for this preprint (which was not certified by peer review) is the author/funder, who has granted medRxiv a license to display the preprint in perpetuity.

All rights reserved. No reuse allowed without permission.

$12820-50$ years), and seropositive elderly ( $\mathrm{n}=11,45 \%$ male, $55 \%$ female; mean age 78 years,

129 age rage $70-91$ years).

130

131 Peripheral blood mononuclear cells (PBMCs) and plasma isolation.

132 Blood samples were collected in heparin-coated tubes (TERUMO;

133 VP-H100K). PBMCs and plasma were separated using Leucosep tupes pre-filled with

134 Ficoll-Paque Plus (Greiner; 163288). After adding $5 \mathrm{~mL}$ of blood and $3 \mathrm{~mL}$ of AIM-V

135 medium (Thermo; 12055091), Leucosep tubes were centrifuged at 1,000 $\mathrm{g}$ at room

136 temperature for 10 min. The white layer containing PBMCs was collected, washed with

$13710 \mathrm{~mL}$ AIM-V medium and centrifuged for $7 \mathrm{~min}$ at $600 \mathrm{~g}$, followed by a second washing

138 with centrifugation for $7 \mathrm{~min}$ at $400 \mathrm{~g}$. PBMC pellets were resuspended in $500 \mu \mathrm{L} \mathrm{CTL}$

139 test medium (Cellular Technology Limited (CTL); CTLT-010). Fresh PBMCs were used

140 for IFN- $\gamma$ ELISpot assays. PBMCs used for flow cytometry analysis and epitope mapping

141 analysis were stored with CTL-cryo ABC media (CTL; CTLC-ABC) in liquid nitrogen.

$143 \quad$ IFN- $\boldsymbol{\gamma}$ ELISpot assay

144 Peptide pools for SARS-CoV-2 S (JPT; PM-WCPV-S-1), N (Miltenyi;130-126-698), and

145 M (Miltenyi;130-126-702) proteins dissolved in DMSO (500 $\mu \mathrm{g} / \mathrm{mL}$ for S) or water (50 
medRxiv preprint doi: https://doi.org/10.1101/2021.07.26.21261082; this version posted July 28,2021 . The copyright holder for this preprint (which was not certified by peer review) is the author/funder, who has granted medRxiv a license to display the preprint in perpetuity.

All rights reserved. No reuse allowed without permission.

$146 \mu \mathrm{g} / \mathrm{mL}$ for $\mathrm{N}$ and $\mathrm{M}$ ) were used for cell stimulation. IFN- $\gamma$ ELISpot assays were performed

147 using Human IFN- $\gamma$ Single-Color Enzymatic ELISpot kits (CTL; hIFNgp-2M), according

148 to the manufacturer's instructions. Briefly, freshly isolated PBMCs $\left(1-4 \times 10^{5}\right.$ cells per

149 well) were stimulated with $1 \mu \mathrm{g} / \mathrm{mL}$ peptide solutions for each SARS-CoV-2 protein for

150 18-20 h. For each sample analysis, negative controls (cells treated with equimolar

151 amounts of DMSO) and positive controls (cells treated with $50 \mathrm{ng} / \mathrm{mL}$ phorbol 12-

152 myristate 13 -acetate (PMA) and $1 \mu \mathrm{g} / \mathrm{mL}$ ionomycin) were included. After incubation,

153 plates were washed and developed with detection reagents included in the kits. Spots were

154 counted using a CTL ImmunoSpot S6 Analyzer. Antigen-specific spot counts were

155 determined by subtracting background spot counts in a negative control well from the

156 wells treated with peptide pools. If $>30$ spots $/ 10^{6}$ PBMCs in the negative control well or

$157<30$ spots $/ 10^{6}$ PBMCs in the positive control well were detected, sample data were

158 excluded from analysis.

\section{$160 \quad$ Flow cytometry}

161 Frozen PBMCs were thawed, washed with CTL wash supplement (CTL; CTL-W-010),

162 and rested in CTL test medium overnight. Then, cells were resuspended in RPMI1640

163 (Gibco) medium supplemented with 5\% (v/v) human AB-serum (PAN-Biotech; P30- 
medRxiv preprint doi: https://doi.org/10.1101/2021.07.26.21261082; this version posted July 28,2021 . The copyright holder for this preprint (which was not certified by peer review) is the author/funder, who has granted medRxiv a license to display the preprint in perpetuity.

All rights reserved. No reuse allowed without permission.

164 2901), seeded into 96-well, U-bottom culture plates $\left(10^{6}\right.$ cells per well), and either left

165 unstimulated (cells treated with equimolar amounts of DMSO) or stimulated with $1 \mu \mathrm{g} / \mathrm{mL}$

166 SARS-CoV-2 $\mathrm{M}$ peptide pool for $7 \mathrm{~h}$ in the presence of $1 \mu \mathrm{g} / \mathrm{mL}$ anti-CD40 (5C3;

167 Biolegend; 334302) and $1 \mu \mathrm{g} / \mathrm{mL}$ anti-CD28 antibodies (CD28.2; Biolegend; 302934).

168 Brefeldin A (1 $\mu \mathrm{g} / \mathrm{mL})$ (Biolegend; 420601) was added for the last $2 \mathrm{~h}$. After stimulation,

169 cells were incubated with anti-Fc receptor-blocking antibody (Biolegend; 422301) and

170 NIR-Zomibie (Biolegend; 423106) and stained with anti-CD3 (OKT3; Biolegend; 1:200),

171 anti-CD4 (clone PPA-T4; Biolegend; 1:200), anti-CD8 (SK1; Biolegend; 1:200), anti-

172 CD45RA (HI100; Biolegend; 1:100), and anti-CCR7 (G043H7; Biolegend; 1:100)

173 antibodies. For intracellular cytokine analysis, cells were subsequently fixed and

174 permeabilized using Foxp3 Staining Buffer Sets (eBioscience; 00-5253-00) and stained

175 with anti-IFN- $\gamma$ (B27; BD; 1:100), anti-TNF- $\alpha$ (MAb11; Biolegend; 1:20) and anti-IL-2

176 (MQ1-17H12; Biolegend; 1:20) antibodies. Samples were analyzed on a Fortessa X-20

177 (BD), and data were analyzed with FlowJo software version 10.7.1 (FlowJo LLC).

179 Matrix peptide pools of SARS-CoV-2 M

180 Matrix peptide pools included in Epitope Mapping Peptide Set SARS-CoV-2 (VME1)

181 (JPT EMPS-WCPV-VME-1) were used to analyze M epitopes recognized by T cells. 
medRxiv preprint doi: https://doi.org/10.1101/2021.07.26.21261082; this version posted July 28,2021 . The copyright holder for this preprint (which was not certified by peer review) is the author/funder, who has granted medRxiv a license to display the preprint in perpetuity.

All rights reserved. No reuse allowed without permission.

182 PBMCs $\left(0.5-1.5 \times 10^{5}\right)$ were stimulated with $1 \mu \mathrm{g} / \mathrm{mL}$ of each M matrix peptide pool (15

183 pools of 6-8 peptides) for $18 \mathrm{~h}$ and subjected to IFN- $\gamma$ ELISpot assays.

184

185 Statistical analysis

186 Unpaired t tests or Mann-Whitney U tests were performed using GraphPad Prism 9.1.0

187 software. Statistical details are provided in figure legends.

188

189

190

191

192

193

194

195

196

197

198

199 
medRxiv preprint doi: https://doi.org/10.1101/2021.07.26.21261082; this version posted July 28, 2021. The copyright holder for this preprint (which was not certified by peer review) is the author/funder, who has granted medRxiv a license to display the preprint in perpetuity.

\section{Results}

202 Age-related differences in SARS-CoV-2-specific T cell responses

203 To assess whether there are age-related differences in SARS-CoV-2-specific T cell

204 responses, we collected peripheral blood from young (20 to 50 years of age) and elderly

205 (>70 years of age) donors in Okinawa between October 2020 and April 2021. These

206 included 18 young and 10 elderly donors who had recovered from mild COVID-19 1-3

207 months prior to blood collection. Antibody tests using freshly purified sera showed that

$20893 \%$ of donors with previously diagnosed COVID-19 and 4\% of those without, were

209 seropositive for SARS-CoV-2 Spike (S). Then we divided donors into 4 groups: young

210 seronegative $(n=45)$, elderly seronegative $(n=41)$, young seropositive $(n=19)$, and elderly

211 seropositive $(\mathrm{n}=11)$.

To compare SARS-CoV-2-specific T cell responses between age groups we

performed Interferon- $\gamma$ (IFN- $\gamma$ ) ELISpot assays using freshly purified peripheral blood

214 mononuclear cells (PBMCs) stimulated with each of 4 peptide pools covering the major

215 viral structural proteins [N-terminal S (S1), C-terminal S (S2), Membrane (M), or

216 Nucleoprotein $(\mathrm{N})$ ]. First, we analyzed the sum of spots formed by IFN- $\gamma$-expressing cells

217 reactive to $\mathrm{S} 1, \mathrm{~S} 2, \mathrm{~N}$, or $\mathrm{M}$ antigens (hereafter referred to as spots of SNM-reactive T 
medRxiv preprint doi: https://doi.org/10.1101/2021.07.26.21261082; this version posted July 28,2021 . The copyright holder for this preprint (which was not certified by peer review) is the author/funder, who has granted medRxiv a license to display the preprint in perpetuity.

All rights reserved. No reuse allowed without permission.

218 cells), indicating the magnitude of SARS-CoV-2-specific T cell responses in each donor.

219 Almost all seropositive donors exhibited strong T cell responses to SARS-CoV-2 antigens

220 regardless of age; the frequency of SNM-reactive spots was $>40$ per $10^{6}$ PBMCs in $92 \%$

221 of seropositive donors. The frequency of SNM-reactive T cells in seronegative donors

222 was more variable than in seropositive donors, but a substantial proportion of

223 seronegative donors exhibit $\mathrm{T}$ cell responses comparable to those of seropositive donors

224 (53\% of young donors and $42 \%$ of elderly donors had $>40$ spots per $\left.10^{6} \mathrm{PBMCs}\right)$. In both

seronegative and seropositive populations, there were no significant differences in the

226 frequency of SNM-reactive T cells between young (seronegative; median:53, IQR:21-96,

seropositive; meidan:312, IQR:75-1509) and elderly (seronegative; median:32, IQR:7-

331, seropositive; meidan:778, IQR:351-2392) (Fig. 1A, 1B).

between young and elderly donors. Among seronegative donors, the frequencies of S-2-

232 However, there were no significant differences in the frequencies of S-1- and M-reactive

$233 \mathrm{~T}$ cells between seronegative young and elderly donors (Fig. 1B). Consistent with

234 previous reports (12), T cell responses to S-2 were higher than S-1 in the seronegative 
medRxiv preprint doi: https://doi.org/10.1101/2021.07.26.21261082; this version posted July 28,2021 . The copyright holder for this preprint (which was not certified by peer review) is the author/funder, who has granted medRxiv a license to display the preprint in perpetuity.

All rights reserved. No reuse allowed without permission.

236 between seropositive young and elderly donors (Fig. 1B).

238 antigen in donors who had $>40$ spots per $10^{6}$ PBMCs. Remarkably, M-specific responses

239 were dominant in 6/23 young and 12/14 elderly seronegative donors (Fig. 2A). In contrast,

240 T cell responses specific to S-1 and S-2 were more prominent than $\mathrm{M}$ in seropositive

241 donors (Fig. 2B). Taken together, these data suggest that although SARS-CoV-2 infection

242 can induce comparable $\mathrm{T}$ cell responses to various viral antigens in young and elderly

243 individuals, pre-existing memory T responses specific to SARS-CoV-2 S and N antigens

244 decrease in elderly people, while M-specific T cell responses are maintained.

246 Phenotypes of M-reactive T cells

247 Given that a proportion of seronegative donors exhibited M-specific responses

248 comparable to those of seropositive donors, we compared phenotypes of M-reactive T

249 cells by flow cytometry analysis. We analyzed 5 seronegative ( 1 young and 4 elderly) and

2505 seropositive ( 2 young and 3 elderly) donors who had high responses to the M peptide

pool (M responders). We stimulated PBMCs with the M peptide pool and stained cells

with anti-CD4 or anti-CD8 antibodies, followed by intracellular cytokine staining with 
medRxiv preprint doi: https://doi.org/10.1101/2021.07.26.21261082; this version posted July 28,2021 . The copyright holder for this preprint (which was not certified by peer review) is the author/funder, who has granted medRxiv a license to display the preprint in perpetuity.

All rights reserved. No reuse allowed without permission.

254 T cells significantly increased expression of IFN- $\gamma$ in both seronegative and seropositive

$255 \mathrm{M}$ responders and at comparable levels (Fig. 3A, 3B).

We next analyzed CD45RA and CCR7 expression to determine proportions of

257 naïve and memory cells among M-reactive CD4 T cells. Although there was significant

258 variation between individuals in proportions of M-reactive CD4 T cells exhibiting naïve

$259\left(\mathrm{CD}^{2} 5 \mathrm{RA}^{-} \mathrm{CCR} 7^{+}\right)$, effector memory $\left(\mathrm{CD}^{-} 5 \mathrm{RA}^{+} \mathrm{CCR}^{-}\right)$, and central memory

260 (CD45RA $^{+} \mathrm{CCR}^{+}$) phenotypes, all M responders had M-reactive memory T cells (Fig.

$2613 \mathrm{C}$ ). There was no obvious difference in the proportion of naïve, effector memory, and

262 central memory CD4 T cells between seronegative and seropositive M responders (Fig.

263 3C).

We also analyzed frequencies of cells expressing IL-2 and TNF- $\alpha$ among M-

reactive CD4 T cells. Although several donors showed increased IL-2 and TNF- $\alpha$

expression upon stimulation with $\mathrm{M}$ in both seronegative and seropositive $\mathrm{M}$ responders,

in seropositive donors, only IL-2 reached statistical significance (Fig. 3D). Seronegative

and seropositive M-responders showed no detectable difference in IL-2 and TFN- $\alpha$

expression in T cells stimulated with M (Fig. 3D). Expression of TNF- $\alpha$ and IL-2 in IFN-

$\gamma$-expressing CD4 $\mathrm{T}$ cells was comparable between seronegative and seropositive $\mathrm{M}$ 
medRxiv preprint doi: https://doi.org/10.1101/2021.07.26.21261082; this version posted July 28,2021 . The copyright holder for this preprint (which was not certified by peer review) is the author/funder, who has granted medRxiv a license to display the preprint in perpetuity.

All rights reserved. No reuse allowed without permission.

272 by CD4 $\mathrm{T}$ cells expressing IFN- $\gamma$ in both seronegative and seropositive $\mathrm{M}$ responders,

273 suggesting that pre-existing M-reactive T cells and SARS-CoV-2-induced memory M-

274 specific T cells might serve similar functions in SARS-CoV-2 infection.

276 Epitopes of SARS-CoV-2 M protein

seropositive donors, we stimulated PBMCs isolated from M responders with SARS-

279 CoV-2 M matrix pools (15 pools of 6-8 peptides) where each of 56 M-derived peptides

280 (15-mers) is allocated to 2 different pools. In seropositive M responders, stimulation

with pools 5 and 13 induced high levels of IFN- $\gamma$ responses (Fig. 4A). These matrix

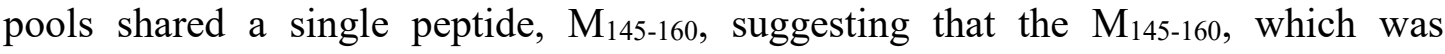

previously identified as an immunodominant viral epitope in COVID-19 convalescent

patents (18), is the epitope recognized by $\mathrm{T}$ cells of seropositive $\mathrm{M}$ responders. In

contrast, in seronegative $\mathrm{M}$ responders, stimulation of PBMCs with many $\mathrm{M}$ matrix

epitopes are recognized by pre-existing $\mathrm{T}$ cells. 
medRxiv preprint doi: https://doi.org/10.1101/2021.07.26.21261082; this version posted July 28, 2021. The copyright holder for this preprint (which was not certified by peer review) is the author/funder, who has granted medRxiv a license to display the preprint in perpetuity.

\section{Discussion}

293 levels of pre-existing SARS-CoV-2 M-specific T cell responses, though the frequency of

294 pre-existing SARS-CoV-2 S- and N-specific T cells in this population is lower. Other

295 recent studies have also reported an age-related decline of S-specific pre-existing T cells

296 (Refs. 19 and L. Loyal et al., manuscript posted on medRxiv DOI:

297 10.1101/2021.04.01.21252379). These data suggest that pre-existing T cells specific to

298 SARS-CoV-2 are heterogeneously affected by age in a target antigen-dependent manner.

299 There was no obvious difference in the sum of IFN- $\gamma$-expressing cells specific to S, N,

300 and $\mathrm{M}$ antigens, suggesting that abundant $\mathrm{M}$-specific $\mathrm{T}$ cells can compensate for the loss

301 of S- and N-specific T cells, at least in the magnitude of T cell-mediated IFN- $\gamma$ production,

302 in elderly individuals. Taken together, these data suggest that the diversity of target

antigen repertoire for pre-existing T cells may decline with age, but the magnitude of pre-

existing $\mathrm{T}$ cell responses can be maintained with $\mathrm{T}$ cells specific to certain viral proteins such as M.

As the frequency of pre-existing T cells specific to viral structural proteins $\mathrm{S}, \mathrm{N}$, and $\mathrm{M}$ is associated with protection from SARS-CoV-2 infection (D. Wyllie et al., 
medRxiv preprint doi: https://doi.org/10.1101/2021.07.26.21261082; this version posted July 28,2021 . The copyright holder for this preprint (which was not certified by peer review) is the author/funder, who has granted medRxiv a license to display the preprint in perpetuity.

manuscript posted on medRxiv DOI: 10.1101/2020.11.02.20222778), focused $\mathrm{M}$

310 lower responses to $\mathrm{S}$ and N. Flow cytometry analyses revealed that CD4 T cells mainly

311 mediate $\mathrm{M}$-specific $\mathrm{T}$ cell responses, and their naïve/memory phenotypes and their

312 capacity to produce IFN- $\gamma$, IL-2, and TNF- $\alpha$ cytokines were comparable between

313 seronegative and seropositive groups. The phenotypic similarity suggests that pre-

314 existing M-reactive T cells may serve similar functions to SARS-CoV-2-induced M-

315 specific memory $\mathrm{T}$ cells. We speculate that pre-existing M-specific CD4 T cells play a

316 protective role in SARS-CoV-2 infection by promoting cellular immunity through IFN- $\gamma$

317 production and humoral immunity by providing $\mathrm{T}$ cell help to $\mathrm{S}$ - and $\mathrm{N}$-specific $\mathrm{B}$ cells

318 via linked recognition. are harmful for some elderly individuals. Several studies suggest that pre-existing SARS-

321 CoV-2-specific T cells are detrimental in COVID-19 (8). In particular, the frequency of M-specific T cells in COVID-19 patients is thought to be a risk factor, as it is correlated with age and severity of disease (8), although how pre-existing M-specific T cells affect magnitude, kinetics and functions of M-specific T cell responses in COVID-19 patients 
medRxiv preprint doi: https://doi.org/10.1101/2021.07.26.21261082; this version posted July 28,2021 . The copyright holder for this preprint (which was not certified by peer review) is the author/funder, who has granted medRxiv a license to display the preprint in perpetuity.

All rights reserved. No reuse allowed without permission.

326 specific $\mathrm{T}$ cells can be speculated. A longitudinal comparison of susceptibility and

327 symptom severity of COVID-19 between individuals with and without high pre-existing

328 M-specific T cell responses might provide insights into this issue.

Despite defects in pre-existing $\mathrm{T}$ cell responses to $\mathrm{S}$ and $\mathrm{N}$, most elderly donors

330 who recovered from mild COVID-19 had abundant $\mathrm{T}$ cells specific to $\mathrm{S}$ and $\mathrm{N}$ antigens

331 at levels comparable to those of young donors, suggesting that elderly individuals can

332 induce $\mathrm{T}$ cell responses against $\mathrm{S}$ and $\mathrm{N}$ antigens upon SARS-CoV-2 infection. However,

our analysis is limited to only a few patients who had recovered from mild COVID-19.

334 Therefore, the relationship between age-related alteration of pre-existing $\mathrm{T}$ cells and $\mathrm{T}$

cell responses during infection in patients with diverse clinical outcomes of COVID-19

should be investigated in a larger, statistically valid test population.

SARS-CoV-2-induced memory T cells persist at least 6 months after infection (20). 
medRxiv preprint doi: https://doi.org/10.1101/2021.07.26.21261082; this version posted July 28,2021 . The copyright holder for this preprint (which was not certified by peer review) is the author/funder, who has granted medRxiv a license to display the preprint in perpetuity.

All rights reserved. No reuse allowed without permission.

344 (18). The amino acid sequence of $\mathrm{M}_{145-160}$ peptide from SARS-CoV-2 shows high

345 homology with SARS-CoV-1 and other coronaviruses (SARS-CoV-1: 81.3\%, NL63:

$34633.0 \%$, OC43: 47.0\%, 229E: 22.7\%, HKU1: 47.0\%). This short M peptide is likely a

347 potent inducer of SARS-CoV-2 M-specific memory T cells. In contrast, pre-existing T

348 cells likely recognize various $\mathrm{M}$ peptides, possibly including $\mathrm{M}_{145-160}$, rather than

349 focusing on this single M peptide, as we observed in epitope mapping analysis.

What induces pre-existing M-specific T cells? Common cold coronaviruses may

induce pre-existing SARS-CoV-2-specific T cell $(22,23)$. Amino acid sequence

homology between SARS-CoV-2 and other common cold coronaviruses is relatively high

for M (NL63: 25.2\%, OC43: 36.9\%, 229E: 26.7\%, HKU1: 32.4\%), S1 (NL63: 11.0\% ,

OC43: 15.4\%, 229E: 12.8\%, HKU1: 15.2\%), S2 (NL63: 27.3\%, OC43: 36.9\%, 229E:

28.0\%, HKU1: 35.3\%), and N (NL63: 22.3\%, OC43: 26.5\%, 229E: 16.2\%, HKU1:

26.5\%). These coronaviruses may induce polyclonal M-specific T cells. Age-related loss

of memory T cells specific to common cold coronavirus S protein (19) supports the

coronavirus infection in elderly people. Our data showing higher frequency of pre- 
medRxiv preprint doi: https://doi.org/10.1101/2021.07.26.21261082; this version posted July 28,2021 . The copyright holder for this preprint (which was not certified by peer review) is the author/funder, who has granted medRxiv a license to display the preprint in perpetuity.

All rights reserved. No reuse allowed without permission.

362 donors, as well as elderly donors, had abundant pre-existing T cells specific to M, but not

363 to $\mathrm{S}$ and $\mathrm{N}$, suggesting that focused $\mathrm{T}$ cell responses to $\mathrm{M}$ are not necessarily due to age-

364 related loss of pre-existing $\mathrm{T}$ cells specific for $\mathrm{S}$ and $\mathrm{N}$ antigens. Interestingly, a recent

365 study reported that $\mathrm{T}$ cells specific to commensal bacteria can cross-react with SARS-

366 CoV-2 S antigen (X. Lu et al., manuscript posted on medRxiv DOI:

367 10.1101/2021.03.23.436573). Similarly, there may be specific microbes that induce pre-

368 existing M-specific T cells. It is worth considering the potential of novel COVID-19 vaccines to induce Mspecific immunity. Current vaccine strategies are to induce S-specific antibody and T cell responses $(24,25)$. Recent studies reported a correlation between the frequency of preexisting S-specific T cells and vaccine-induced S-specific T cell responses (L. Loyal et al., manuscript posted on medRxiv DOI: 10.1101/2021.04.01.21252379), which suggests a role of pre-existing S-specific $\mathrm{T}$ cells in cognate $\mathrm{T}$ cell help. However, elderly individuals likely would not benefit fully from pre-existing S-specific T cells. To enhance vaccine efficacy among the elderly, it might be reasonable to consider a strategy to induce not only S-specific, but also M-specific immunity, using vaccines based on inactivated viruses or M-fused S antigens. Linked recognition of $\mathrm{M}$-specific $\mathrm{T}$ helper cells by $\mathrm{S}$ specific B cells can promote S-specific antibody production by overcoming the defect of 
medRxiv preprint doi: https://doi.org/10.1101/2021.07.26.21261082; this version posted July 28,2021 . The copyright holder for this preprint (which was not certified by peer review) is the author/funder, who has granted medRxiv a license to display the preprint in perpetuity.

All rights reserved. No reuse allowed without permission.

380 cognate $\mathrm{T}$ cell help in elderly individuals. Further characterization of M-specific $\mathrm{T}$ cells

381 in young and elderly may provide new insights into vaccine-induced immunity that is less

382 affected by age.

383

384 Acknowledgements

385 We thank physicians and nurses at KIN oncology Clinic for excellent support to collect

386 blood samples from donors. We also thank Steven Aird for editing manuscript. We are

387 also grateful to OIST Graduate University for its generous funding of the Immune Signal

388 Unit. 
medRxiv preprint doi: https://doi.org/10.1101/2021.07.26.21261082; this version posted July 28, 2021. The copyright holder for this preprint (which was not certified by peer review) is the author/funder, who has granted medRxiv a license to display the preprint in perpetuity.

\section{References}

390 1. Merad, M., and J. C. Martin. 2020. Pathological inflammation in patients with COVID-19: a key role for monocytes and macrophages. Nature Reviews Immunology 20: 355-362.

2. O’Driscoll, M., G. Ribeiro Dos Santos, L. Wang, D. A. T. Cummings, A. S. specific mortality and immunity patterns of SARS-CoV-2. Nature 590:

3. Takahashi, T., M. K. Ellingson, P. Wong, B. Israelow, C. Lucas, J. Klein, J. differences in immune responses that underlie COVID-19 disease outcomes. Nature 588: 315-320. interconnected - obesity, impaired metabolic health and COVID-19. 
medRxiv preprint doi: https://doi.org/10.1101/2021.07.26.21261082; this version posted July 28, 2021. The copyright holder for this preprint (which was not certified by peer review) is the author/funder, who has granted medRxiv a license to display the preprint in perpetuity. All rights reserved. No reuse allowed without permission.

Nature Reviews Endocrinology 17: 135-149.

408 5. Krammer, F. 2020. SARS-CoV-2 vaccines in development. Nature 586: 516-527.

6. Fajgenbaum, D. C., and C. H. June. 2020. Cytokine Storm. New England Journal of Medicine 383: 2255-2273.

7. De Candia, P., F. Prattichizzo, S. Garavelli, and G. Matarese. 2021. T Cells: Warriors of SARS-CoV-2 Infection. Trends in Immunology42: 18-30. specific $\mathrm{T}$ cell responses and correlations with COVID-19 patient predisposition. Journal of Clinical Investigation 130: 6477-6489. 183: 996-1012.e1019. 
medRxiv preprint doi: https://doi.org/10.1101/2021.07.26.21261082; this version posted July 28, 2021. The copyright holder for this preprint (which was not certified by peer review) is the author/funder, who has granted medRxiv a license to display the preprint in perpetuity. All rights reserved. No reuse allowed without permission.

10. Chen, G., D. Wu, W. Guo, Y. Cao, D. Huang, H. Wang, T. Wang, X. Zhang, H. Chen, H. Yu, X. Zhang, M. Zhang, S. Wu, J. Song, T. Chen, M. Han, S. Li, X. Luo, J. Zhao, and Q. Ning. 2020. Clinical and immunological features of severe and moderate coronavirus disease 2019. Journal of Clinical Investigation 130: 2620-2629.

11. Le Bert, N., H. E. Clapham, A. T. Tan, W. N. Chia, C. Y. L. Tham, J. M. Lim, K. Kunasegaran, L. W. L. Tan, C.-A. Dutertre, N. Shankar, J. M. E. Lim, L. J. Sun, M. Zahari, Z. M. Tun, V. Kumar, B. L. Lim, S. H. Lim, A. Chia, Y.-J. Tan, P. A. Tambyah, S. Kalimuddin, D. Lye, J. G. H. Low, L.-F. Wang, W. Y. Wan, L. Y. Hsu, A. Bertoletti, and C. C. Tam. 2021. Highly functional virus-specific cellular immune response in asymptomatic SARSCoV-2 infection. Journal of Experimental Medicine 218.

12. Braun, J., L. Loyal, M. Frentsch, D. Wendisch, P. Georg, F. Kurth, S. Hippenstiel, M. Dingeldey, B. Kruse, F. Fauchere, E. Baysal, M. Mangold, L. Henze, R. Lauster, M. A. Mall, K. Beyer, J. Rohmel, S. Voigt, J. Schmitz, S. Miltenyi, I. Demuth, M. A. Muller, A. Hocke, M. Witzenrath, N. Suttorp, F. Kern, U. Reimer, H. Wenschuh, C. Drosten, V. M. Corman, C. Giesecke-Thiel, L. E. Sander, and A. Thiel. 2020. SARS-CoV-2-reactive T 
medRxiv preprint doi: https://doi.org/10.1101/2021.07.26.21261082; this version posted July 28,2021 . The copyright holder for this preprint (which was not certified by peer review) is the author/funder, who has granted medRxiv a license to display the preprint in perpetuity.

cells in healthy donors and patients with COVID-19. Nature 587: 270-274.

444 13. Le Bert, N., A. T. Tan, K. Kunasegaran, C. Y. L. Tham, M. Hafezi, A. Chia,

14. Woldemeskel, B. A., A. K. Kwaa, C. C. Garliss, O. Laeyendecker, S. C. Ray,

15. Bacher, P., E. Rosati, D. Esser, G. R. Martini, C. Saggau, E. Schiminsky, J. 
medRxiv preprint doi: https://doi.org/10.1101/2021.07.26.21261082; this version posted July 28, 2021. The copyright holder for this preprint (which was not certified by peer review) is the author/funder, who has granted medRxiv a license to display the preprint in perpetuity. All rights reserved. No reuse allowed without permission.

461 16. Chen, Z., and E. John Wherry. 2020. T cell responses in patients with COVID-19. Nature Reviews Immunology 20: 529-536.

463 17. Sahin, U., A. Muik, E. Derhovanessian, I. Vogler, L. M. Kranz, M. Vormehr,

18. Keller, M. D., K. M. Harris, M. A. Jensen-Wachspress, V. V. Kankate, H. human antibody and TH1 T cell responses. Nature 586: 594-599. Lang, C. A. Lazarski, J. Durkee-Shock, P.-H. Lee, K. Chaudhry, K. Webber, A. Datar, M. Terpilowski, E. K. Reynolds, E. M. Stevenson, S. Val, Z. Shancer, N. Zhang, R. Ulrey, U. Ekanem, M. Stanojevic, A. Geiger, H. Liang, F. Hoq, A. A. Abraham, P. J. Hanley, C. R. Cruz, K. Ferrer, L. Dropulic, K. Gangler, P. D. Burbelo, R. B. Jones, J. I. Cohen, and C. M. Bollard. 2020. SARS-CoV-2-specific T cells are rapidly expanded for 
medRxiv preprint doi: https://doi.org/10.1101/2021.07.26.21261082; this version posted July 28,2021 . The copyright holder for this preprint (which was not certified by peer review) is the author/funder, who has granted medRxiv a license to display the preprint in perpetuity.

therapeutic use and target conserved regions of the membrane protein.

19. Saletti, G., T. Gerlach, J. M. Jansen, A. Molle, H. Elbahesh, M. Ludlow, W.

20. Jiang, X.-L., G.-L. Wang, X.-N. Zhao, F.-H. Yan, L. Yao, Z.-Q. Kou, S.-X.

Wang, E.-T. Li, X. Wei, Q.-Y. Wang, X.-F. Wang, W.-Y. Sun, Y.-W. Gao, responses to SARS-CoV-2 in COVID-19 patients three months after

21. Ng, O.-W., A. Chia, A. T. Tan, R. S. Jadi, H. N. Leong, A. Bertoletti, and Y.-J. Tan. 2016. Memory T cell responses targeting the SARS coronavirus persist up to 11 years post-infection. Vaccine 34 : 2008-2014.

22. Sagar, M., K. Reifler, M. Rossi, N. S. Miller, P. Sinha, L. F. White, and J. P. less-severe COVID-19. Journal of Clinical Investigation 131. 
medRxiv preprint doi: https://doi.org/10.1101/2021.07.26.21261082; this version posted July 28, 2021. The copyright holder for this preprint (which was not certified by peer review) is the author/funder, who has granted medRxiv a license to display the preprint in perpetuity. All rights reserved. No reuse allowed without permission.

23. Mateus, J., A. Grifoni, A. Tarke, J. Sidney, S. I. Ramirez, J. M. Dan, Z. C. Burger, S. A. Rawlings, D. M. Smith, E. Phillips, S. Mallal, M. Lammers, P. Rubiro, L. Quiambao, A. Sutherland, E. D. Yu, R. Da Silva Antunes, J. Greenbaum, A. Frazier, A. J. Markmann, L. Premkumar, A. De Silva, B. Peters, S. Crotty, A. Sette, and D. Weiskopf. 2020. Selective and crossreactive SARS-CoV-2 T cell epitopes in unexposed humans. Science 370: 89-94.

24. Corbett, K. S., D. K. Edwards, S. R. Leist, O. M. Abiona, S. BoyogluBarnum, R. A. Gillespie, S. Himansu, A. Schäfer, C. T. Ziwawo, A. T. Dipiazza, K. H. Dinnon, S. M. Elbashir, C. A. Shaw, A. Woods, E. J. Fritch, D. R. Martinez, K. W. Bock, M. Minai, B. M. Nagata, G. B. Hutchinson, K. Wu, C. Henry, K. Bahl, D. Garcia-Dominguez, L. Ma, I. Renzi, W.-P. Kong, S. D. Schmidt, L. Wang, Y. Zhang, E. Phung, L. A. Chang, R. J. Loomis, N. E. Altaras, E. Narayanan, M. Metkar, V. Presnyak, C. Liu, M. K. Louder, W. Shi, K. Leung, E. S. Yang, A. West, K. L. Gully, L. J. Stevens, N. Wang, D. Wrapp, N. A. Doria-Rose, G. Stewart-Jones, H. Bennett, G. S. Alvarado, M. C. Nason, T. J. Ruckwardt, J. S. McLellan, M. R. Denison, J. D. Chappell, I. N. Moore, K. M. Morabito, J. R. Mascola, R. S. Baric, A. Carfi, and B. S. 
medRxiv preprint doi: https://doi.org/10.1101/2021.07.26.21261082; this version posted July 28,2021 . The copyright holder for this preprint (which was not certified by peer review) is the author/funder, who has granted medRxiv a license to display the preprint in perpetuity.

All rights reserved. No reuse allowed without permission.

517 25. Polack, F. P., S. J. Thomas, N. Kitchin, J. Absalon, A. Gurtman, S. Lockhart, 
medRxiv preprint doi: https://doi.org/10.1101/2021.07.26.21261082; this version posted July 28, 2021. The copyright holder for this preprint (which was not certified by peer review) is the author/funder, who has granted medRxiv a license to display the preprint in perpetuity.

\section{Figure Legends}

\section{Fig. 1. Altered pre-existing T cell responses to SARS-CoV-2 structural proteins in}

\section{7 elderly donors.}

528 PBMCs isolated from seronegative (A) and seropositive (B) young (20-50 years of age)

529 and elderly ( $>70$ years of age) donors were stimulated with peptide pools for SARS-CoV-

$5302 \mathrm{~S}, \mathrm{~N}$, and M proteins and subjected to IFN- $\gamma$ ELISpot analysis. Spot-forming units

531 representing the frequency of IFN- $\gamma$-secreting cells in seronegative young $(n=45)$,

532 seronegative elderly $(n=41)$, seropositive young $(n=19)$, and seropositive elderly $(n=11)$

533 are shown. The sum of spots formed by cells stimulated with S, N, and M (SNM) is also

534 shown. Statistical comparisons between age groups utilized the Mann-Whitney test.

$535 * \mathrm{P}<0.05$, ns: not significant.

Fig. 2. M-specific pre-existing $\mathrm{T}$ cell responses predominate in elderly donors.

538 Ratios of spots formed by cells stimulated with SARS-CoV-2 S, N, and M peptide pools

539 in ELISpot data (in Fig. 1.) were analyzed in seronegative (A) and seropositive (B) donors

540 who had $>40$ spots $/ 10^{6}$ PBMCs in the sum of spots formed by cells stimulated with $\mathrm{S}, \mathrm{N}$,

541 and $\mathrm{M}$. 
medRxiv preprint doi: https://doi.org/10.1101/2021.07.26.21261082; this version posted July 28, 2021. The copyright holder for this preprint (which was not certified by peer review) is the author/funder, who has granted medRxiv a license to display the preprint in perpetuity.

All rights reserved. No reuse allowed without permission.

\section{4 phenotypes.}

545 PBMCs isolated from seronegative $(n=5)$ and seropositive $(n=5) M$ responders were

546 stimulated with an M peptide pool for 7 hours and analyzed by flow cytometry. The flow

547 cytometry gating strategy was shown in Supplemental Figure 1. (A) Dot plots represent

548 IFN- $\gamma$ expression in CD4 and CD8 T cells of subject \#31 (seronegative, $>70$ years of age).

549 (B) Percentages of IFN- $\gamma$-expressing cells among CD4 and CD8 T cells were analyzed.

550 (C) Percentages of naïve (Tn), central memory (Tcm), and effector memory (Tem) among

551 IFN- $\gamma$-expressing cells stimulated with M. (D, E) Percentages of TNF- $\alpha-$ and IL-2-

Statistical analysis utilized unpaired two-tailed Student's t tests. ${ }^{*} \mathrm{P}<0.05$, ns: not significant.

Fig. 4. SARS-CoV-2 M epitopes recognized by $T$ cells. 
medRxiv preprint doi: https://doi.org/10.1101/2021.07.26.21261082; this version posted July 28,2021 . The copyright holder for this preprint (which was not certified by peer review) is the author/funder, who has granted medRxiv a license to display the preprint in perpetuity.

All rights reserved. No reuse allowed without permission.

561 ELISpot analysis. Spot-forming units representing the frequency of IFN- $\gamma$-secreting cells.

562 Blue and orange bars indicate results of young and elderly donors, respectively. 


\section{A Seronegative}

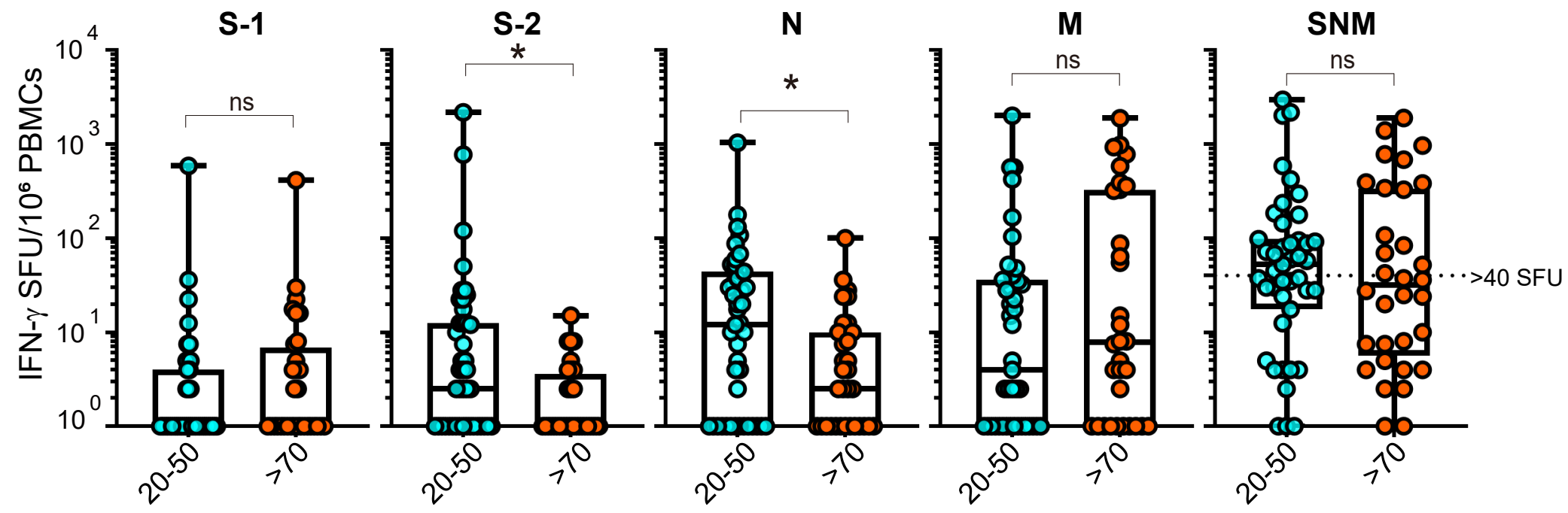

B

Seropositive

S-1

S-2

$\mathbf{N}$

M

SNM

.
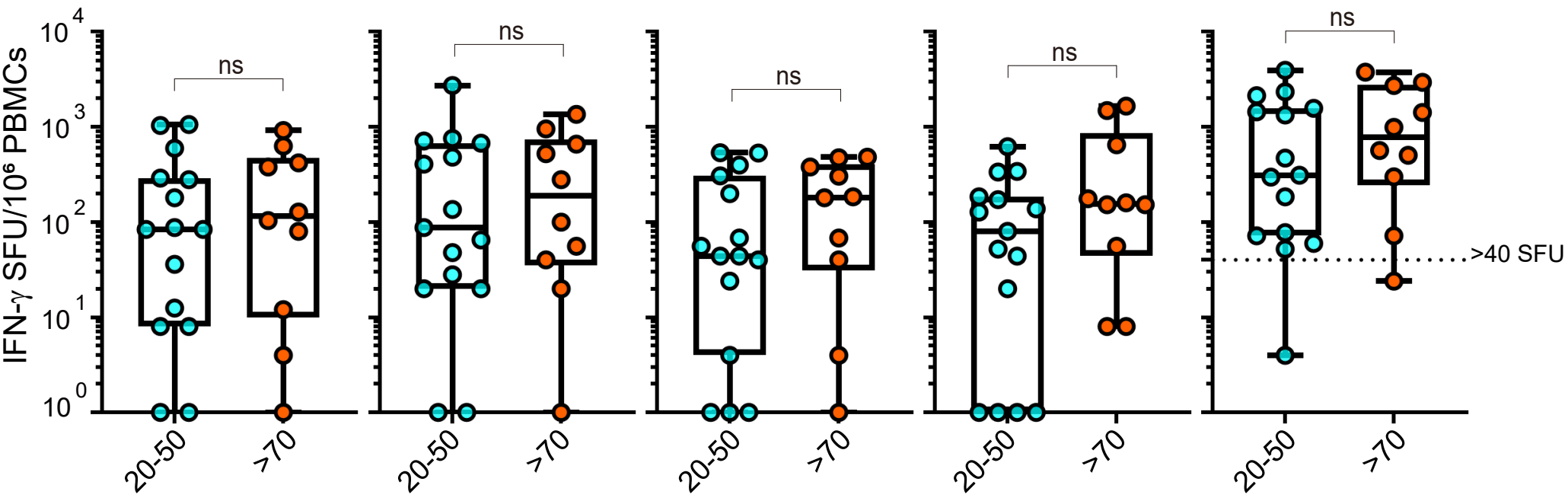
Figureaffariv preprint doi: https://doi.org/10.1101/2021.07.26.21261082; this version posted July 28, 2021. The copyright holder for this preprint A

(which was not certified by peer review) is the author/funder, who has granted medRxiv a license
All rights reseged. No reuse allowed without permission.
Seronegat Ve

Subject ID

All rights resened. No reuse allowed without permission.

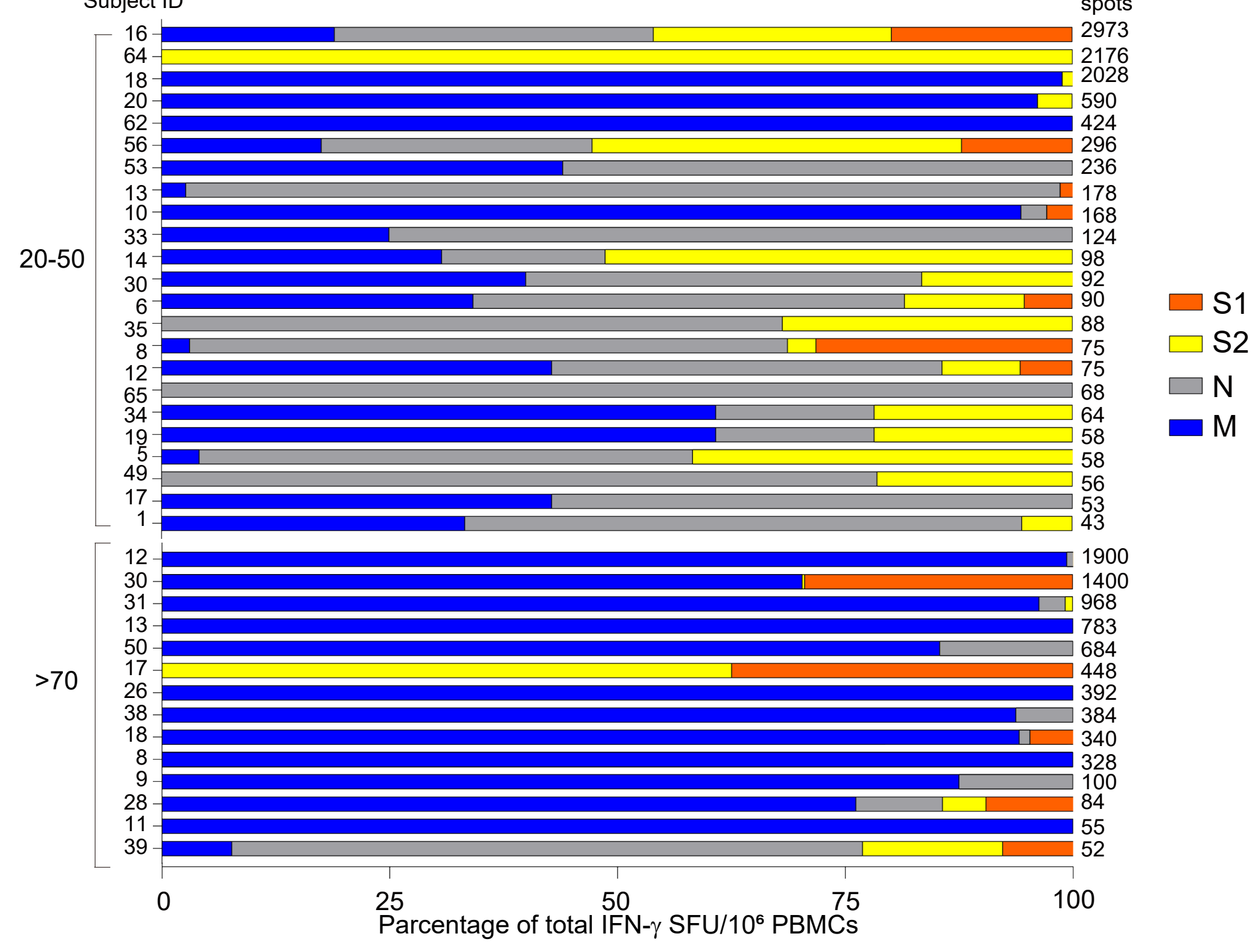

B

Subject ID

Seropositive

SNM

reactive

spots

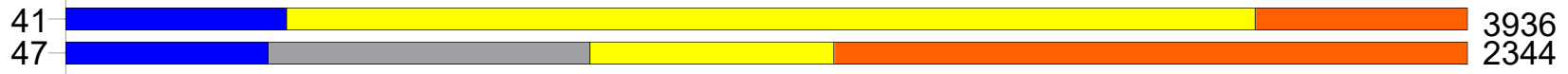

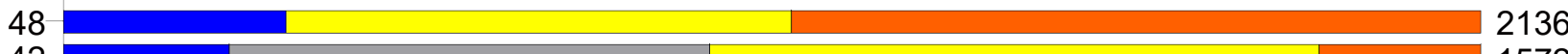

\begin{tabular}{l|l|l|}
\hline $42-$ & \\
\hline
\end{tabular}

$22=1445$

$23-1333$

\begin{tabular}{l|l|l|l|l}
$20-50$ & 43 & & 472 \\
& 38 & 312
\end{tabular}

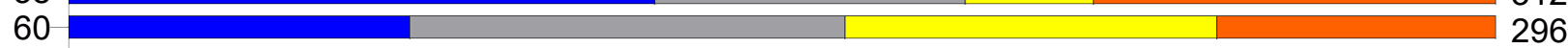

$44-\square 184$

$28-78$

$40-\square 64$

$55-\square \quad 1 \quad \square 2$

66 - 53

47

$33-$

34

$45-$
51
36
36

36

46

37

0

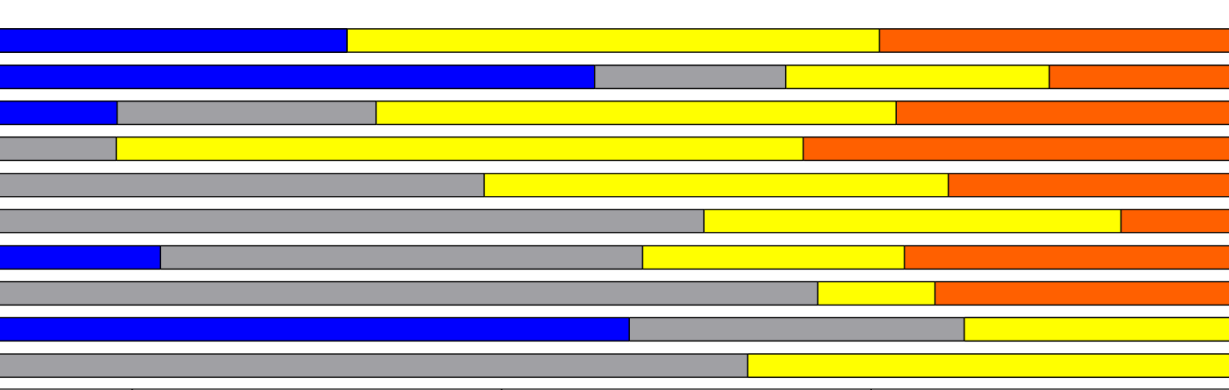

3752

2940

2716

1420

1196

992

\section{4}

504

300

60

$\begin{array}{ll}25 & 50 \\ \text { Parcentage of total IFN- } \gamma \text { SFU/10 } & 75 \\ \text { PBMCs }\end{array}$

100 


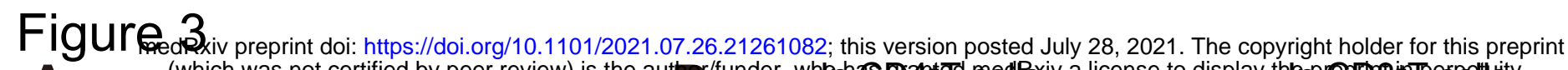

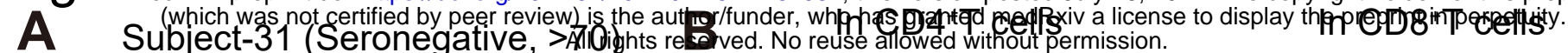

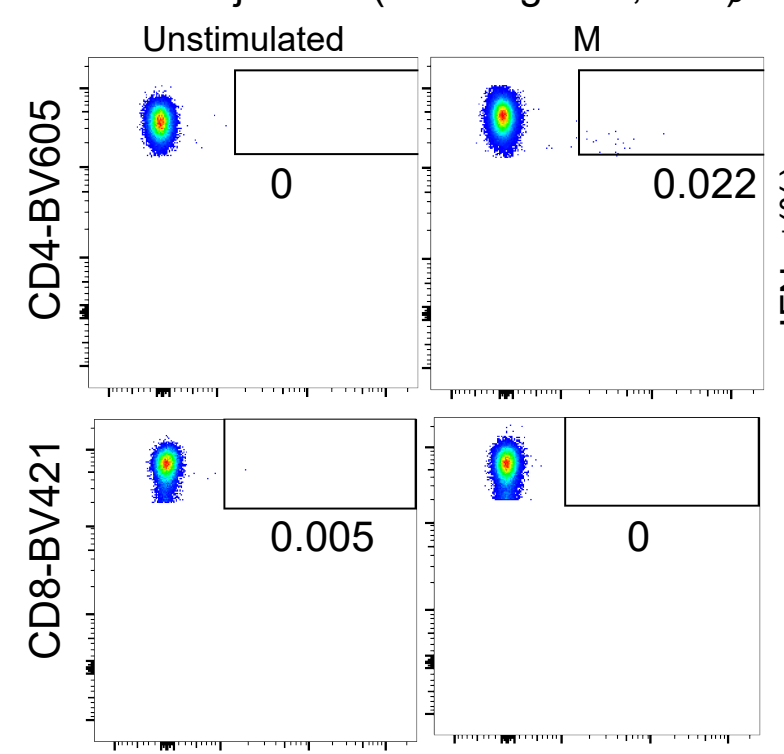

IFN- $\gamma$-AF700
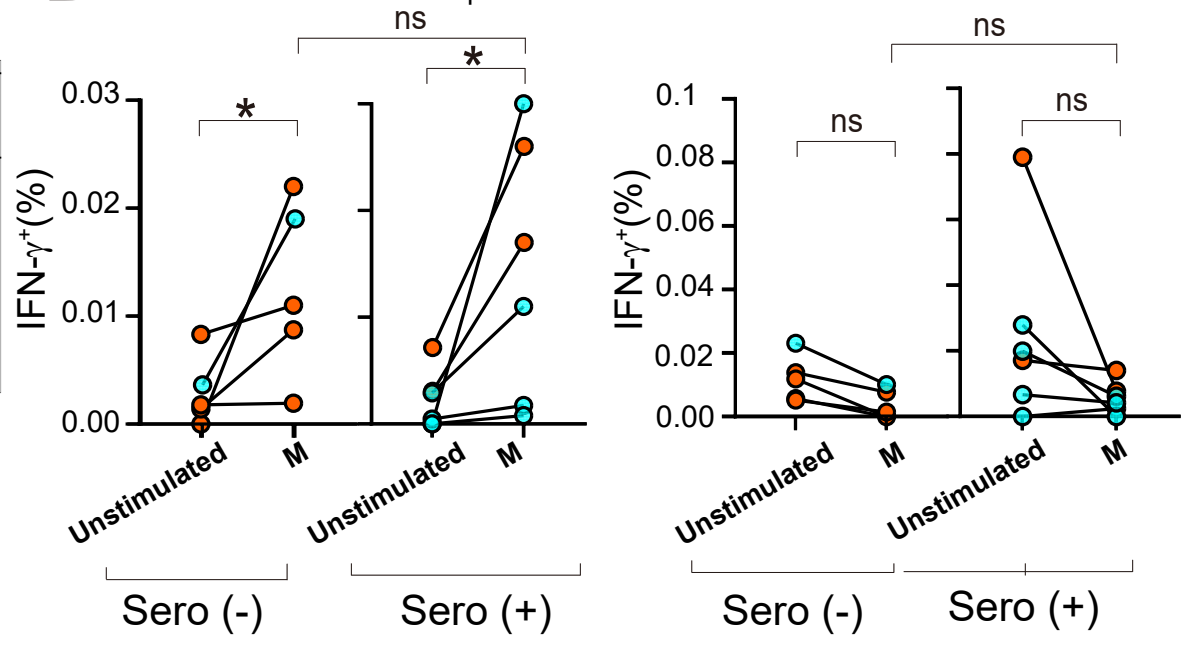

C

$\mathrm{Tn}$

$\mathrm{Tcm}$

M-responsive donors

$0<50 \quad 0>70$

$\left(\mathrm{CD}^{2} 5 \mathrm{RA}^{+} \mathrm{CCR}^{+}\right) \quad\left(\mathrm{CD}^{+} 5 \mathrm{RA}^{-} \mathrm{CCR}^{+}\right) \quad\left(\mathrm{CD}^{-} 5 \mathrm{RA}^{-} \mathrm{CCR} 7^{-}\right)$

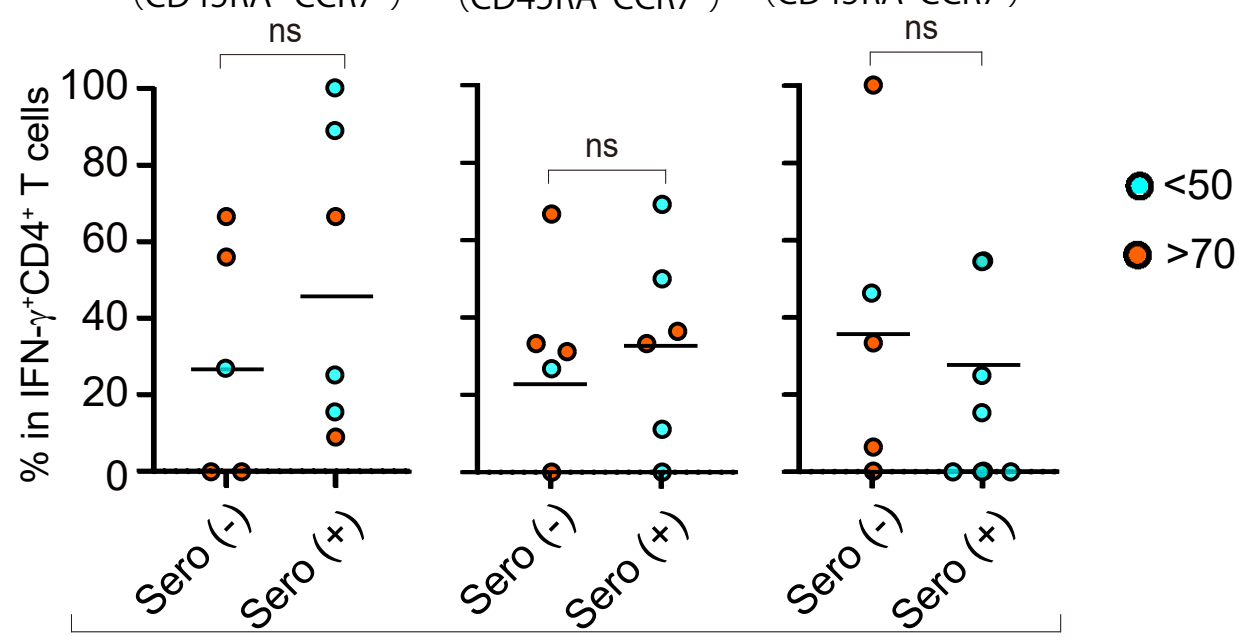

Stimulated with $\mathrm{M}$

D

In $\mathrm{CD}^{+} \mathrm{T}$ cells

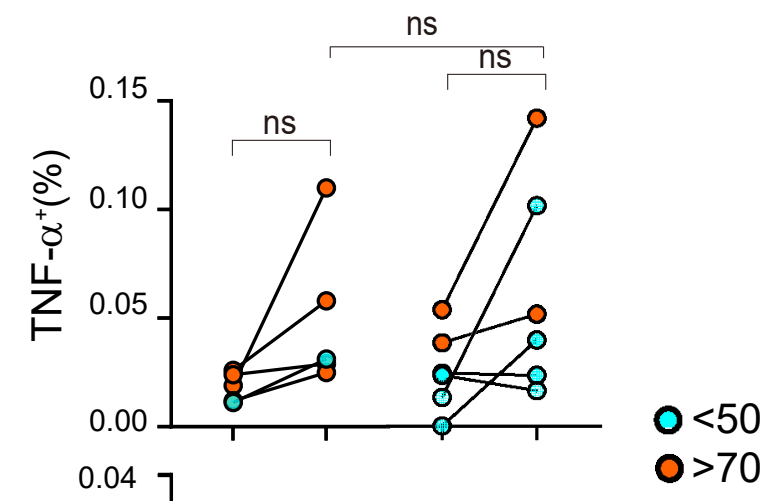

E
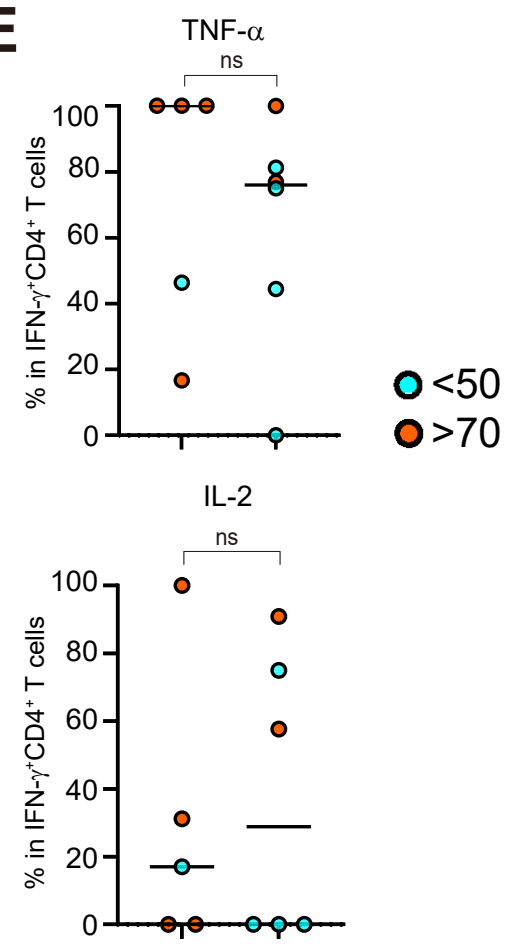

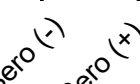

Stimulated with $\mathrm{M}$ M-responsive donors 
medRxiv preprint doi: https://doi.org/10.1101/2021.07.26.21261082; this version posted July 28, 2021. The copyright holder for this preprint Figure (w/4h was not certified by peer review) is the author/funder, who has granted medRxiv a license to display the preprint in perpetuity.

A
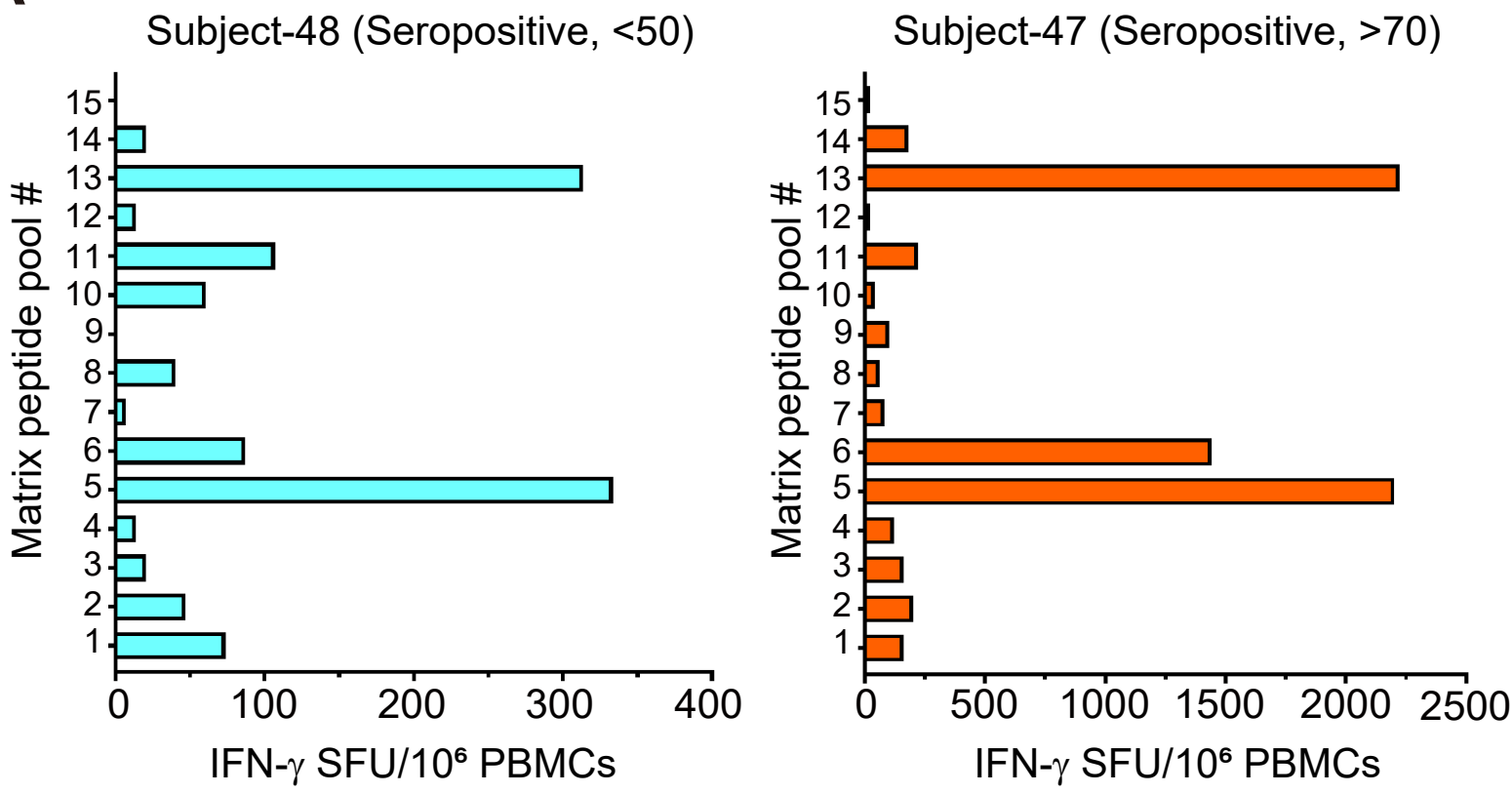

B

Subject-8 (Seronegative, >70)

\section{Subject-50 (Seronegative, >70)}
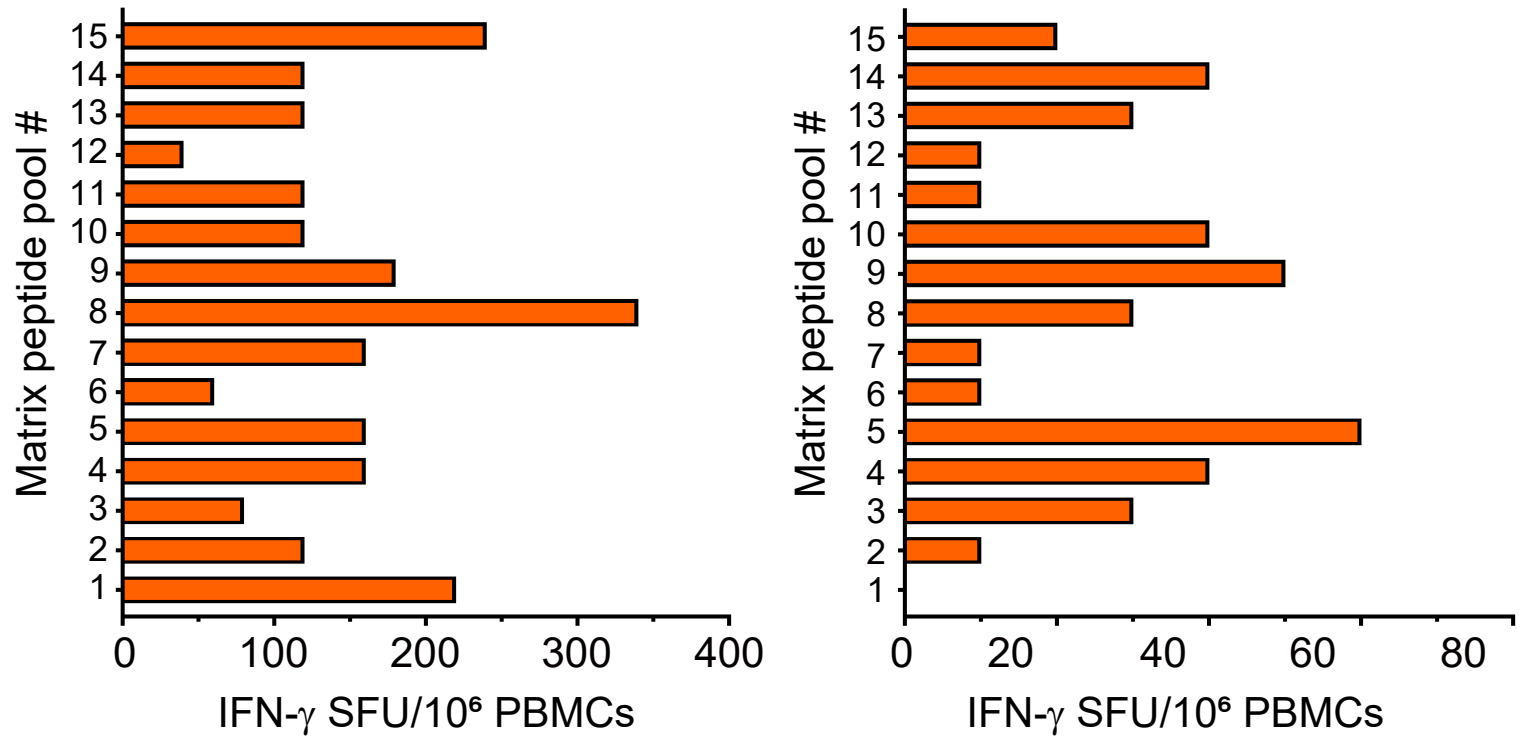